\title{
Academic Major, Gender, Personal Values, And Reactions To An Ethical Dilemma
}

\author{
Jane E. Baird, (Email: jane.baird@mnsu.edu), Minnesota State University
} Robert C. Zelin, II, (Email: robert.zelin@mnsu.edu), Minnesota State University Paul J. Brennan, (Email: paul.brennan@mnsu.edu), Minnesota State University

\begin{abstract}
Recent corporate scandals have increased public interest in the area of business ethics. This study examines the relationship of gender and choice of academic major to personal values and to ethical choices, and the relationship of personal values to ethical choices. Two hundred fifty three subjects read a case that presented a tax evasion dilemma. The subjects responded to a series of action statements related to the ethical dilemma and completed a personal values survey. The responses to the action statements were used to calculate a tax compliance score. Participants were also asked to make a choice as to whether the taxpayer should or should not report all of the taxable income. The results indicate that both the tax compliance score and the tax payment choice differed by gender and academic major. Furthermore, gender differences were found on five of the ten personal value constructs and academic major differences were found on four of the ten personal value constructs. With regard to the relationship of personal values to ethical choices, it was found that three of the personal value constructs were correlated with the compliance score and the tax payment decision.
\end{abstract}

\section{INTRODUCTION}

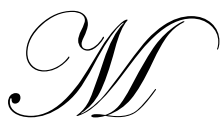

uch has been written in the popular press about unethical business practices in recent years. Business schools are under increasing pressure to infuse more ethics instruction into the curriculum, and businesses are struggling with ways to foster ethical behaviors in their organizations. An increased awareness of underlying factors that may influence ethical choices can enable educators and businesses to better identify ways to promote appropriate behavior. This study examines the impact of three such factors: gender, choice of academic major, and personal values. The decision context utilized involves a small businessman who performs some work on a cash basis and is struggling with the decision of whether or not to report the income on his tax return.

\section{PRIOR RESEARCH}

\section{Personal Values}

Bardi and Schwartz (2003) describe personal values as motivational, representing "broad goals that apply across contexts and time." That is, an individual's values should motivate his or her behavior and choices in a variety of situations, including personal and family relationships as well as behavior at work. Schwartz (1992) describes ten values that have been extensively validated as distinct values that are common across cultures (Bardi and Schwartz, 2003). These values are defined in Exhibit One. Schwartz's theory of values explains that these ten broad values have predictable relationships in motivating behavior, with some values being compatible with each other and others being in direct conflict with each other regarding certain behaviors. According to this theory, for example, Conformity and Tradition values would motivate similar behaviors and are also congruent with Security and Benevolence values, but are in conflict with values such as Stimulation and Hedonism. Power and Achievement values are congruent, but are in conflict with Universalism and Benevolence. Some behaviors relate to several values while others are driven primarily by one value. 


\begin{tabular}{|l|l|}
\hline \multicolumn{1}{|c|}{ Schwartz (1992) 10 Broad Values } \\
\hline \multicolumn{1}{|c|}{ Value } & \multicolumn{1}{c|}{ Description } \\
\hline Achievement & Personal success through demonstrating competence according to social standards \\
\hline Benevolence & Preservation and enhancement of the welfare of people with whom one is in frequent personal contact \\
\hline Conformity & $\begin{array}{l}\text { Restraint of actions, inclinations, and impulses likely to upset or harm others and violate social expectations or } \\
\text { norms }\end{array}$ \\
\hline Hedonism & Pleasure and sensuous gratification for oneself \\
\hline Power & Social status and prestige, control or dominance over people and resources \\
\hline Security & Safety, harmony and stability of society, of relationships, and of self \\
\hline Self-Direction & Independent thought and action-choosing, creating, exploring \\
\hline Stimulation & Excitement, novelty, and challenge of life \\
\hline Tradition & $\begin{array}{l}\text { Respect, commitment, and acceptance of the customs and ideas that traditional culture or religion provide the } \\
\text { self }\end{array}$ \\
\hline Universalism & Understanding, appreciation, tolerance, and protection for the welfare of all people and of nature. \\
\hline
\end{tabular}

Prior research provides some indication that the personal values of males and females differ. Giacomino and Eaton (2003) found that the overall value systems of male and female accounting alumni were similar, but that differences were significant on four individual values. Males valued Wisdom and An Exciting Life more than the females, while Pleasure and Equality were rated as more important by the women (Giacomino and Eaton, 2003). Giacomino and Akers (1998) used the Schwartz (1992) values scale and found differences between males and females on 2 of the 10 value constructs. The male business students rated both conformity and power significantly higher than the females did. Akers and Giacomino (2000) also found gender differences in the values of audit and tax professionals. Pinac-Ward et al. (1995) studied the values of men and women accounting professors and found no significant gender differences.

There is also evidence that students majoring in different subjects have differing personal values. Giacomino and Akers (1998) used the Schwartz (1992) scale to examine the personal values of accounting majors as compared to other business majors. They found significant differences between Accounting and nonaccounting majors for 13 of 56 values included in the scale and for half of the 10 general values. Nonaccounting majors rated Achievement, SelfDirection, Hedonism, Stimulation, and Power higher than did the accountants. Baker (1976) found that accounting majors differed from other majors on 8 out of 36 values studied.

\section{Ethical Behavior}

Various studies have explored how gender and choice of major correlate with ethical decisions or behaviors, without consideration of underlying personal values. Goodman and Crawford (1974) compared reactions of business and nonbusiness students to ethical scenarios and found no statistical differences. Hawkins and Cocanougher (1972), however, found that business majors overall viewed unethical business practices as more acceptable than nonbusiness majors did. Knotts et al. (2000) found just the opposite - that business majors rated questionable business practices as more unethical than did their nonbusiness counterparts. Giacomino (1992) studied ethical evaluations and choices of business students across different academic majors and found no significant differences. Laczniak and Inderrieden (1987) and Barnett et al. (1994) found no differences in ethical judgments for students in different majors, while Beltramini et al. (1984) found significant differences. Looking at differences across business majors, Fulmer and Cargile (1987) found that accounting students viewed various dilemmas more ethically than did other business students, but that there was no significant difference across majors in ethical choices. Arrington and Reckers (1985) found that business majors were more tolerant of tax evasion behavior than were nonbusiness majors.

In terms of gender, some researchers examining gender differences in ethical perceptions and/or behaviors have found no significant differences between men and women (Derry, 1989; Giacomino, 1992; Houston, 1977; Kidwell et al., 1987; McNichols and Zimmerer, 1985; and Serwinek, 1992). However, many other researchers have found that ethical judgments of men and women do differ. For example, Barnett et al. (1994) presented 24 scenarios to students and found that the female students rated all 24 scenarios as less ethical than did the male students. 
Ruegger and King (1992) also found differences in the ethical judgments of men and women, with the females being more ethically-oriented than the males. Knotts et al. (2000) also found that females rated behaviors as significantly more unethical than their male counterparts. Terpstra et al. (1993) also found that men made more unethical choices than women in regard to insider trading scenarios. Both Hasseldine and Hite (2003) and Baldry (1987) found that men were more likely to evade taxes than were women. Many other studies have supported the findings that women may be more ethical than men (Barnett and Karson, 1987; Hetherington and Feldman, 1964; Jones and Gautschi, 1988; Kelley et al., 1990; Miesing and Preble, 1985 and Roskens and Dizney, 1966). However, there are also studies that have found males to react more ethically than females (Gable and Topol, 1988; Hunt and Chonko, 1984; Jacobsen et al., 1970 and Lane and Schaupp, 1989). Many of these studies of gender differences in ethical choices have used college students as subjects, and it is important to note that the differences between males' and females' ethical perceptions may change or diminish with age.

\section{Relationship Of Values To Ethical Behavior}

Researchers studying the potential link between individuals' personal values and their ethical choices have found mixed results. Nonis and Swift (2001) found that students with a "nondriven" value profile were statistically more likely to make unethical choices than either internally driven or externally driven students. Donoho et al. (2003) also reported a link between values and ethical decisions. They found that students who valued achievement more did not view the presented unethical sales behaviors as disfavorably as students who rated high on relationship values. Brief et al. (1996), in contrast, did not find a significant relationship between the personal values of managers and decisions of those managers to either misrepresent or not misrepresent their companies' financial statements.

In terms of tax compliance behaviors specifically, Reckers et al. (1994) found that individuals who view paying taxes as a moral issue are less likely to commit tax evasion behaviors. Trivedi et al. (2003) also reported that a taxpayer's personal values and moral reasoning significantly affected decisions regarding tax compliance. Several studies have linked views of societal norms to tax compliance behavior. Welch et al. (2005) found that taxpayers who feel tax evasion is more the norm than the exception are significantly more apt to evade taxes themselves and are more tolerant of tax evasion by others. Chang and Lai (2004) also found that individuals viewing tax evasion as the norm in society are more likely to commit tax evasion. Interestingly, Arrington and Reckers (1985) reported that students generally viewed tax compliance, rather than tax evasion, as the norm in society. They found that students did not always disapprove of tax evaders equally in all situations; their disapproval increased toward individuals with a history of tax evasion.

This paper seeks to expand on the previous literature by exploring the association of personal values, gender, and academic major on one type of ethical choice: whether or not to report all of the taxpayer's taxable income. Examining the three factors in one study enables the evaluation of interaction effects among the three in order to better understand how these factors relate to actual ethical behaviors.

\section{METHOD}

Packets were distributed to students in nine undergraduate business courses at one Midwestern state university. These courses are required of College of Business majors and certain other majors outside of the College of Business. The students were asked to participate voluntarily in the survey for extra credit points and were assured that the responses would be anonymous. Each packet contained an instructions page, a one-page background reading on the U.S. tax system, a scenario presenting a taxable income reporting dilemma, a questionnaire regarding students' attitudes toward the dilemma, the 56-item Schwartz (1992) personal values scale, and a brief demographic questionnaire.

There were two versions of the short background reading, with each student receiving only one version of the reading. One version emphasized the positive impact that the tax system has on society, while the other version presented a more negative picture of the tax system by portraying it as inequitable. This information was gathered for purposes of another study. Analysis of Variance indicated that the version of reading had no impact on any of the 
variables in the current study, either directly or via interactions with the other variables. Therefore, this variable is not considered further in this study.

The scenario presented an ethical dilemma faced by a hard-working small business owner. The man had been paid cash for one job, and while he knew that legally he was required to report that income, reporting it would cause him to owe taxes he felt he could not afford to pay. Because he was paid in cash, he also knows it would be unlikely that he would be caught by the Internal Revenue Service if he failed to report the income. The students were asked what they felt the businessman should do. They were first asked to rate their agreement with six statements, each on a scale of one (strongly disagree) to seven (strongly agree). The statements can be found in Exhibit Two. Each of the statements offers a particular rationale for favoring compliance or noncompliance. The compliance statements argue that compliance should be chosen on alternative grounds of morality, safety, and societal responsibility. The noncompliance statements imply that cheating is widespread and taxpayers with more resources than the subject taxpayer practice greater evasion, detection is unlikely or the taxpayer should consider his own needs more than the government's. A "compliance" score was computed for each subject by adding their responses to the first three questions and then subtracting their responses to the last three questions.

Students were also asked for a definite recommendation as to what the business man should do, with only two choices provided: (1) he should report the income or (2) he should not report the income.

\begin{tabular}{|r|l|}
\hline a. & $\begin{array}{l}\text { Compliance Score Components } \\
\text { He should report the income. Tax evasion is illegal and unethical. He can afford the payment, particularly if he is given } \\
\text { some time to pay the balance. } \\
\text { be should report the income. If he complies with the tax law, he doesn't have to worry about the possibility of getting } \\
\text { caught and having other transactions that might be audited. He can afford the payment, particularly if he is given some } \\
\text { time to pay the balance. }\end{array}$ \\
c. & $\begin{array}{l}\text { He should report the income. Compliance is his duty as a citizen. He can afford the payment, particularly if he is given } \\
\text { some time to pay the balance. }\end{array}$ \\
d. & $\begin{array}{l}\text { He should not report the payment. The money means much more to him than the government. People with far more } \\
\text { resources than him cheat the government of far more money and he doesn't have the opportunities to avoid taxes that } \\
\text { many with higher incomes have. }\end{array}$ \\
e. & $\begin{array}{l}\text { He should not report the payment. The money means much more to him than the government. It's not that much money } \\
\text { anyway and the government is unlikely to ever discover his omission. Even if the government finds out, he's unlikely to } \\
\text { suffer very serious consequences. } \\
\text { fe should not report the income. The money means much more to him than the government. He pays plenty in taxes } \\
\text { already considering his income. }\end{array}$ \\
\hline
\end{tabular}

The Schwartz (1992) values scale includes 56 values, with 30 on one list and 26 on a second list. The students were instructed to first read through each list of values and choose the most important value and then the least important value to them in their everyday lives. Then, they were instructed to rate each value on each list, using a scale of -1 (opposed to my values) to 7 (of extreme importance). These value ratings are then used to calculate each student's rating based on Schwartz's (1992) ten broad values. Prior studies have established strong internal validity and cross-cultural applicability of using 45 of the value items from the list of values to compute the 10 value scores (Bardi and Schwartz, 2003). The ratings on each value associated with one of the 10 general values are averaged to calculate the score for the general value. For example, each subject's conformity score was computed as the average of his or her ratings for four values: politeness, obedience, self-discipline, and honoring parents and elders.

The demographic questions included the student's academic major, gender, their year in college (i.e. freshman), and whether the student had taken a tax course. For this study, only students who had not taken a tax course were included so that prior training in tax law would not affect the responses. 


\section{HYPOTHESES}

The hypotheses are divided into three groups: three hypotheses based on gender, three hypotheses based on academic major and one hypothesis based on the relationship between values and ethical choice. Prior research revealed mixed results with regard to ethical choices made by women and men. However, a predominant number of those studies found women to react more ethically then men, and in two studies, Hasseldine and Hite (2003) and Baldry (1987), the authors found that men were more likely to evade taxes than were women. Therefore, it is hypothesized that:

H1: Females will have a higher compliance score than males.

H2: Females will be more likely than the males to indicate the taxpayer should report the income.

Numerous studies have found that value differences exist in the gender arena. However, there has not been a great deal of consistency as to those differentiations. Therefore, we hypothesize that there will be value differences by gender, without a priori predictions of what those differences will be. Formally stated, we hypothesize that:

H3: Males and Females will differ significantly in their value ratings.

The second group of hypotheses centers on the differences in ethical choice and values by academic major. Prior research has once again yielded mixed results. However, evidence does suggest that, at least under some circumstances, students majoring in different subjects will react differently to ethical dilemmas. The nature of those differences appears to vary across circumstances. While one might posit that accountants, as the "watch dogs" of the financial world, would be most likely to comply with the tax law, this study seeks to determine if differences exist in reactions to this tax evasion scenario, without a priori predictions of the nature of those differences. Therefore, it is hypothesized that:

H4: Compliance score will differ significantly by academic major.

H5: The decision to report the income will differ significantly by academic major.

Giacomino and Akers (1998), as well as Baker (1976) found that the personal values of accounting majors differed from those of other business majors. Understanding more about the values held by students in different majors and professionals in different fields may help both academics and business leaders learn more about how to tap into those values to foster ethical behaviors. Therefore, it is hypothesized that:

H6: Value ratings will differ significantly by academic major.

Certainly an end goal of business ethics research is to assist in increasing the ethical behavior of business professionals. Understanding the association between an individual's personal values and his or her ethical choices could be a critical link in that process. Several researchers have found a link between values and ethical choices (e.g. Nonis and Swift, 2001; Donoho et al. 2003, Trivedi et al. 2003). The prior research on tax compliance suggests that the ultimate decision to comply or not comply with the tax law may be essentially a function of a desire to conform to societal norms (e.g. Welch et al. 2005, Chang and Lai, 2004). If this is true, then the Schwartz (1992) values theory would suggest that individuals who score high on Conformity and its congruent value of Tradition would be most likely to report the tax, whereas those scoring high on the conflicting values of Hedonism and Stimulation would be most likely to make the opposite decision, not to pay the tax. Therefore, it is hypothesized that:

H7: The Conformity and Tradition values will correlate significantly and positively with the compliance score and decision to report income, while the Hedonism and Stimulation values will correlate significantly and negatively with the compliance score and decision to report income. 


\section{RESULTS}

\section{Demographics}

The survey was returned by 276 students. Of the surveys returned, 23 responses were significantly incomplete and therefore deemed unusable, leaving a total of 253 usable responses. A majority of the students were College of Business majors, with 62 of the students majoring in Accounting, 34 in Finance, 68 in Management, 48 in Marketing and 41 in other majors outside of the College of Business. The other majors include construction management, sports management, and aviation, among others. There were 129 males and 124 females. Approximately half of the students, 123 , were juniors, while 45 were sophomores, 80 were seniors and one was a nondegree student (four students did not list their major).

\section{Tests Of Hypotheses By Gender}

An Analysis of Variance was used to test the first hypothesis, that the females would have a higher compliance score than the males. The compliance scores of the females were significantly higher than those of the males ( $\mathrm{p}=.003$ ). The mean score for the females was 5.81 compared to a mean score for the males of 2.29. Therefore, $\mathrm{H} 1$ is supported.

A Pearson Chi-Square test was used to test hypothesis two, that females would be more likely than males to recommend reporting the income. For the male students, 75 out of 127 (59 percent) said the businessman should pay the tax. For the women, 85 out of 123 (69 percent) said the businessman should pay the tax. A higher percentage of the women made the more ethical choice, and there was a statistically significant gender effect in the pay/no pay decision at the .05 level (one-tailed $\mathrm{p}=.048$ ). Therefore, $\mathrm{H} 2$ is supported.

For hypothesis three, Analysis of Variance was used to test differences in ratings on the ten values by the men and the women. The males and females differed significantly on half of the ten personal value constructs at the .05 significance level: Power ( $\mathrm{p}=.001)$, Self-direction $(\mathrm{p}=.009)$, Universalism ( $\mathrm{p}=.008)$, Benevolence $(\mathrm{p}=.000)$, and Conformity $(\mathrm{p}=.007)$. The mean score for men was higher on the Power variable. Whereas, the mean score was higher for women on the other four personal values constructs. Thus, hypothesis three is partially supported. The mean values by gender are detailed in Table One.

These findings only partially agree with those of Giacomino and Akers (1998). The authors only found significant differences on two value constructs, Power and Conformity, which were both higher for men.

\begin{tabular}{|c|c|c|}
\hline \multicolumn{3}{|c|}{ Table One } \\
Mean Compliance Scores And Value Constructs By Gender \\
\hline Item & Male & Female \\
\hline Compliance Score & 2.2891 & 5.8065 \\
\hline Achievement & 5.3953 & 5.5121 \\
\hline Benevolence & 5.3907 & 5.8548 \\
\hline Conformity & 5.0601 & 5.4004 \\
\hline Hedonism & 5.4341 & 5.4879 \\
\hline Power & 4.0717 & 3.5427 \\
\hline Security & 5.0297 & 5.1226 \\
\hline Self-Direction & 5.0760 & 5.3790 \\
\hline Stimulation & 4.7313 & 4.6344 \\
\hline Tradition & 4.2884 & 4.5258 \\
\hline Universalism & 4.5659 & 4.8800 \\
\hline
\end{tabular}




\section{Tests Of Hypotheses By Academic Major}

For hypothesis four, an Analysis of Variance indicated a significant difference on compliance scores across academic majors $(\mathrm{p}=.037)$. Mean compliance scores were highest for the Accounting majors at 6.63 , followed by 4.83 for the Marketing majors, 4.37 for the Non-College of Business majors, 2.39 for the Finance majors, and 1.65 for the Management majors. Hypothesis four is supported, therefore, with the Accounting majors exhibiting the most ethical choices and the Finance and Management majors exhibiting the least ethical choices. Post-hoc comparisons using the least significant differences test reveal that the only statistically significant pair wise differences occur in comparisons of Accounting majors against Finance ( $\mathrm{p}=.038)$ and Management $(\mathrm{p}=.003)$ majors.

In terms of the bivariate decision that the businessman should pay the tax or not pay the tax, the Chi-Square results for academic major was significant at the .05 level $(\mathrm{p}=.018)$. Seventy-four percent of the Accounting majors indicated he should pay the tax, compared to 73 percent of the majors from outside the College of Business, 69 percent of the Marketing majors, 54 percent of the Management majors, and 48 percent of the Finance majors. Therefore, hypothesis five is supported.

Hypothesis six is also partially supported. Students choosing different academic majors differed significantly on four out of the 10 values: Power ( $\mathrm{p}=.005)$, Stimulation ( $\mathrm{p}=.001)$, Self-direction $(\mathrm{p}=.008)$, and Tradition (.029). The mean value scores by academic major are shown in Table Two.

Hypothesis seven is partially supported. As predicted, correlation analysis revealed that the pay/not pay decision was significantly correlated with Tradition $(\mathrm{p}=.008)$ and Conformity $(\mathrm{p}=.008)$. Universalism was also significantly and positively correlated with the decision to pay the tax $(\mathrm{p}=.003)$, although this relationship was not predicted. The higher the students scored on these three values, the more likely they were to say the businessman should pay the tax. Likewise, the compliance score was significantly associated with the same three values (Universalism, $\mathrm{p}=.014$; Tradition, $\mathrm{p}=.008$; and Conformity, $\mathrm{p}=.000$ ). The higher the students rated the three values, the higher their compliance score. The Universalism value correlation was not predicted, but is not in conflict with the theory. It is not directly adjacent to the Conformity and Tradition values on the spectrum, but is not on the opposite side of the spectrum either. The conflicting values Hedonism and Stimulation were not significantly correlated with either the compliance score ( $\mathrm{p}=.151$ for Hedonism, $\mathrm{p}=.718$ for Stimulation) or the recommendation to pay the tax ( $\mathrm{p}=.108$ for Hedonism, $\mathrm{p}=.633$ for Stimulation), but the direction of the association was in conformity with the theory. The higher the individuals scored on Hedonism and Stimulation, the lower their compliance scores and the less likely they were to recommend paying the tax.

\begin{tabular}{|c|c|c|c|c|c|}
\hline \multicolumn{7}{|c|}{ Table Two } \\
Mean Compliance Scores and Value Ratings by Academic Major \\
\hline Item & Accounting & Finance & Management & Marketing & Other \\
\hline Compliance Score & 6.6290 & 2.3939 & 1.6471 & 4.8333 & 4.3659 \\
\hline Achievement & 5.3589 & 5.2721 & 5.4485 & 5.5729 & 5.6098 \\
\hline Benevolence & 5.6161 & 5.4176 & 5.5971 & 5.8625 & 5.5366 \\
\hline Conformity & 5.1532 & 5.0588 & 5.1360 & 5.4894 & 5.3232 \\
\hline Hedonism & 5.2742 & 5.5588 & 5.5221 & 5.7708 & 5.1951 \\
\hline Power & 3.2944 & 3.8382 & 4.0919 & 3.8564 & 4.0671 \\
\hline Security & 5.0226 & 4.8824 & 4.9735 & 5.2894 & 5.2390 \\
\hline Self-Direction & 5.0903 & 4.8824 & 5.2059 & 5.5792 & 5.3268 \\
\hline Stimulation & 4.1882 & 4.5882 & 4.8382 & 5.0000 & 4.8862 \\
\hline Tradition & 4.1194 & 4.1294 & 4.5588 & 4.6542 & 4.5171 \\
\hline Universalism & 4.7359 & 4.5257 & 4.6048 & 4.8984 & 4.8384 \\
\hline
\end{tabular}

To better understand the relationship of gender, choice of major, and personal values to the compliance scores, a stepwise regression was performed with all 10 values, gender and academic major as potential variables. 
The resulting regression equation included just 4 factors, including 3 values, with conformity as the most significant. The model is:

Compliance Score $=-1.92+4.04$ Conformity -1.01 Hedonism - 2.94 Management -1.74 Security

This suggests that these factors are the best predictors of the compliance score. Hedonism and Conformity values are directly opposite each other on Schwartz's (1992) values spectrum and are showing significant and opposing effects on the compliance score. The Security value could be significant in the regression due to the scenario involving an individual whose financial security would be threatened if he reported all of the taxable income and had to pay the tax. The more important Security was to the individual, the lower their compliance score was. Dummy variables were constructed for the majors, with the Accounting major being the excluded class. The Management majors, as a whole, reported significantly lower compliance scores than the other majors, especially the Accountants, and therefore the model predicts on average their compliance scores would be approximately 3 points below the other majors. The gender effect fails to appear in the stepwise regression because gender is confounded with major in our sample. Accounting majors were predominantly female while Management and Finance majors were predominantly male.

\section{CONCLUSIONS AND RECOMMENDATIONS}

One finding of the study was that both the tax compliance score and the tax payment decision did differ by gender and academic major, and that the compliance score and choice were highly correlated. However, a small minority of students indicating the taxpayer should pay the tax had low compliance scores. Virtually no students indicating the payment should not be made had high compliance scores. Therefore, it appears there can be a conflict for some individuals who might empathize with the taxpayer's situation and feel he might deserve to keep the money (hence a low compliance score), but when faced with an ultimate choice feel they should conform to legal and societal expectations in recommending payment of the tax. The compliance score was a mixed measure of appropriate taxpayer action combined with a composite of differing attitudes toward rationales for compliance or noncompliance. The tax payment choice required a binary decision about the best choice of action for the taxpayer. The survey evidence illustrates that attitudes are sometimes in conflict with stated decision choices. Another finding was that gender or academic major differences were not found on all ten personal value constructs. However, gender differences were found on five (Power, Self-direction, Universalism, Benevolence and Conformity) of the constructs and academic major differences were found on four (Power, Stimulation, Self-direction and Tradition) of the constructs.

When the relationship between personal values and ethical choices was examined, it was found that three (Tradition, Conformity, and Universalism) constructs correlated significantly with both the compliance score and the tax payment decision. It was hypothesized that Tradition and Conformity would be correlated. The additional finding about Universalism is logical because Universalism was defined by Schwartz (1992) as "Understanding, appreciation, tolerance and protection for the welfare of all people and nature." Therefore, if one is concerned about the "welfare of all people," then one would make the decision to pay the tax.

In interpreting the results of this study, one should be mindful of the study's limitations. Although the size of the sample was robust, the sample was wholly comprised of students at one university. Therefore, the results may not generalize to all groups. Additionally, the subjects were only presented with one ethical dilemma so the results may not apply to every ethical dilemma.

A further examination could explore the relationship between values, gender, major and specific rationales for ethical choices. Researchers could also incorporate a variety of ethical dilemmas to examine situational differences. 


\section{REFERENCES}

1. Akers, M. D. and Giacomino, D. E. (2000), Ethics and the Accountants' Code of Conduct, The Journal of Applied Business Research, (16), pp. 87-95.

2. Arrington, C. E. and Reckers, P. M. J. (1985), A Social-Psychological Investigation into Perceptions of Tax Evasion, Accounting \& Business Research, (summer), pp. 163-176.

3. Baker, C. R. (1976), An Investigation of Differences in Values: Accounting majors vs. Nonaccounting Majors, The Accounting Review, (53), pp. 886-893.

4. Baldry, J. C. (1987), Income tax evasion and the tax schedule: Some experimental results, Public Finance, (42), pp. 357-383.

5. Bardi, A. and Schwartz, S. H. (2003), Values and Behavior: Strength and Structure of Relations, Personality and Social Psychology Bulletin, (29), pp. 1207-1220.

6. Barnett, J. H. and Karson, M. J. (1987), Personal Values and Business Decisions: An Exploratory Investigation, Journal of Business Ethics, (6), pp. 371-382.

7. Barnett, T., Brown, G., and Bass, K. (1994). The Ethical Judgments of College Students Regarding Business Issues, Journal of Education for Business, (69), pp. 333-338.

8. Beltramini, R. F., Peterson, R. A., and Kozmetsky, G. (1984). Concerns of College Students Regarding Business Ethics, Journal of Business Ethics, (3), 195-200.

9. Brief, A. P., Dukerich, J. M., Brown, P. R., and Brett, J. F. (1996), What's Wrong with the Treadway Commission Report? Experimental Analyses of the Effects of Personal Values and Codes of Conduct on Fraudulent Financial Reporting, Journal of Business Ethics, (15), pp. 183-198.

10. Chang, J. and Lai, C. (2004), Collaborative Tax Evasion and Social Norms: Why Deterrence Does Not Work, Oxford Economic Papers, (56), pp. 344-368.

11. Derry, R. (1989), An Empirical Study of Moral Reasoning Among Managers, Journal of Business Ethics, (8), pp. 855-862.

12. Donoho, C. L., Herche, J., and Swenson, M. J. (2003), A Cross Cultural Study of the Effects of Achievement and Relationship Values on Student Evaluations of Personal Selling Ethical Dilemmas, Marketing Education Review, (13), pp. 53-63.

13. Fulmer, W. E. and Cargile, B. R. (1987), Ethical Perceptions of Accounting Students: Does Exposure to a Code of Professional Ethics Help?, Issues in Accounting Education, (2 ) pp. 207-219.

14. Gable, M. and Topol, M. T. (1988), Machiavellianism and the Department Store Executive, Journal of Retailing, (64), pp. 68-84.

15. Giacomino, D. E. (1992), Ethical Perceptions of Accounting Majors and Other Business Majors: An Empirical Study, Accounting Educators' Journal (4), pp. 1-26.

16. Giacomino, D. E. and Akers, M. D. (1998), An Examination of the Differences Between Personal Values and Value Types of Female and Male Accounting and Nonaccounting Majors, Issues in Accounting Education, (13), pp. 565-584.

17. Giacomino, D. E. and Eaton, T. V. (2003), Personal Values of Accounting Alumni: An Empirical Examination of Differences by Gender and Age, Journal of Managerial Issues, (15), pp. 369-380.

18. Goodman, C. and Crawford, C. M. (1974), Young Executives- A Source of New Ethics, Personnel Journal, (53), pp. 180-187.

19. Hasseldine, J. and Hite, P. A. (2003), Framing, Gender, and Tax Compliance, Journal of Economic Psychology, (24), pp. 517-533.

20. Hawkins, D. I. and Cocanougher, A. B. (1972), Student Evaluations of the Ethics of Marketing Practices: the Role of Marketing Education, Journal of Marketing, (36), pp. 61-64.

21. Hetherington, E. M. and Feldman, S. E., (1964), College Cheating as a Function of Subject and Situational Variables, Journal of Educational Psychology, (55), pp. 212-218.

22. Houston, J. P. (1977), The Assessment and Prevention of Answer Copying on Undergraduate MultipleChoice Examinations, Research in Higher Education, (68), pp. 729-735.

23. Hunt, S. D. and Chonko, L. B. (1984), Marketing and Machiavellianism, Journal of Marketing, (48), pp. 3042 . 
24. Jacobson, L. I., Berger, S. E., and Millham, J. (1970), Individual Differences in Cheating During a Temptation Period When Confronting Failure, Journal of Personality and Social Psychology, (15), pp. 4856.

25. Jones, T. M. and Gautschi, F. H. (1988), Will the Ethics of Business Change? A survey of Future Executives, Journal of Business Ethics, (7), pp. 231-248.

26. Kelley, S. W., Ferrell, O. C., and Skinner, S. J. (1990), Ethical Behavior Among Marketing Researchers: An Assessment of Selected Demographic Characteristics, Journal of Business Ethics, (9), pp. 681-688.

27. Kidwell, J. M., Stevens, R. E., and Bethke, A. L, (1987), Differences in Ethical Perceptions Between Male and Female Managers: Myth or Reality?, Journal of Business Ethics, (6), pp. 489-493.

28. Knotts, T. L., Lopez, T. B., and Mesak, H. I. (2000), Ethical Judgments of College Students: An Empirical Analysis, Journal of Education for Business, (January/February), pp. 158-163.

29. Laczniak, G. and Inderrieden, E. J. (1987), The influence of Stated Organizational Concern Upon Ethical Decision Making, Journal of Business Ethics, (6), pp. 297-307.

30. Lane, M. S. and Schaupp, D. (1989), Ethics in Education: A Comparative Study, Journal of Business Ethics, (8), pp. 943-949.

31. McNichols, C. W. and Zimmerer, T. W. (1985), Situational Ethics: An Empirical Study of Differentiators of Student Attitudes, Journal of Business Ethics, (4), pp. 175-180.

32. Miesing, P. and Preble, J. F. (1985), A Comparison of Five Business Philosophies, Journal of Business Ethics, (4), pp. 465-476.

33. Nonis, S. and Swift, C. O. (2001), Personal Value Profiles and Ethical Business Decisions, Journal of Education for Business, (76), pp. 251-256.

34. Pinac-Ward, S., Ward, D. R., and Wilson, T. E., Jr. (1995), University Accounting Professors: An Examination of Personal Values, Accounting Educators' Journal, (7), pp. 39-53.

35. Reckers, P. M., Sanders, D. L., and Roark, S. J. (1994). The Influence of Ethical Attitudes on Taxpayer Compliance, National Tax Journal, ( XLVII), pp. 825-836.

36. Roskens, R. W. and Dizney, H. F. (1966), A study of Unethical Behavior in High School and College, The Journal of Educational Research, (59), pp. 321-324.

37. Ruegger, D. and King, E. W. (1992). A Study of the Effect of Age and Gender Upon Student Business Ethics, Journal of Business Ethics, (11), pp. 179-186.

38. Schwartz, S. H. (1992), Universals in the Content and Structure of Values: Theoretical Advances and Empirical Tests in 20 Countries, Advances in Experimental Social Psychology, (25), pp. 1-65.

39. Serwinek, P. J. (1992), Demographic and Related Differences in Ethical Views Among Small Businesses, Journal of Business Ethics, (11), pp. 555-566.

40. Terpstra, D. E., Rozell, E. J., and Robinson, R. K, (1993), The Influence of Personality and Demographic Variables on Ethical Decisions Related to Insider Trading, The Journal of Psychology, (127), pp. 375-389.

41. Trivedi, V. U., Shehata, M., and Lynn, B. (2003), Impact of Personal and Situational Factors on Taxpayer Compliance: An Experimental Analysis, Journal of Business Ethics, (47), pp. 175-197.

42. Welch, M., Xu, Y., Bjarnason, T., Petie, T., O’Donnell, P., and Magro, P. (2005), 'But Everybody Does It...': The Effects of Perceptions, Moral Pressures, and Informal Sanctions on Tax cheating, Sociological Spectrum, (25), pp. 21-52. 